\title{
1-Methylcyclopropene postharvest treatment and their effect on apple quality during long-term storage time
}

\author{
Joanna Kolniak-Ostek • Aneta Wojdyło • \\ Jarosław Markowski $\cdot$ Karolina Siucińska
}

Received: 3 March 2014 / Revised: 3 May 2014 / Accepted: 12 May 2014 / Published online: 10 June 2014

(C) The Author(s) 2014. This article is published with open access at Springerlink.com

\begin{abstract}
The aim of this study was to evaluate the effect of the postharvest treatment by 1-methylcyclopropene (1-MCP) and storage time on the apple physicochemically quality. The effects of apple storage during 6 months on basic parameters such as dry weight, total soluble solids and titratable acidity, composition of phenolics, antioxidant activity and sensory evaluation were studied to evaluate the potential applicability of long-time stored apples for consumption and processing. Long-time storage of apples resulted in a higher dry matter but decreases total soluble solids and titratable acidity in all examined cultivars (cv.) of apples. The total phenolics determined by HPLC in fresh apples ranged from $1,243 \mathrm{mg}$ in 'Idared' $\mathrm{cv}$. to $1,435 \mathrm{mg} / \mathrm{kg}$ in 'Shampion' cv. During storage, the decrease of polyphenolic content has been observed, in 'Shampion' cv., it was higher than in 'Idared' cv. Similar effects were observed for antioxidant activity. Comparing quality of fruits just after harvest, it was found that cultivar affects most of the investigated sensory attributes with the exception of ripe apple smell, crispness, crunchiness and the overall texture score. In general, 'Shampion' cv. apples got higher ranks for sweetness, taste and the overall quality, whereas 'Idared' $\mathrm{cv}$. were perceived as sourer, which is in arrangement with
\end{abstract}

J. Kolniak-Ostek · A. Wojdyło $(\bowtie)$

Department of Fruit, Vegetable and Grain Technology,

Wroclaw University of Environmental and Life Sciences, 37/41

Chełmońskiego St., 51630 Wrocław, Poland

e-mail: anetajb@op.pl; aneta.wojdylo@up.wroc.pl

J. Kolniak-Ostek

e-mail: joanna.kolniak-ostek@up.wroc.pl

J. Markowski $\cdot$ K. Siucińska

Department of Fruit Storage and Processing, Research Institute of Horticulture, 18 Pomologiczna St., 96100 Skierniewice, Poland instrumental measurements. The results of presented study demonstrate that apples after storage, especially 'Shampion' cv., can be a valuable sensory attributes for food product and consumption. This study indicates that the use of 1-MCP treatment in long-term storage of apples is promising for maintaining the eating quality of fruits, however, in some extent may affect their antioxidant compounds content.

Keywords Storage $\cdot 1$-MCP $\cdot$ Firmness $\cdot$ Phenolic compounds $\cdot$ Antioxidant activity $\cdot$ Sensory evaluation

\section{Introduction}

There is a growing interest in food compounds with a possible health-protecting capacity. In epidemiological research, the intake of fruits and vegetables has been widely acknowledged to be inversely related to cancer incidence and cardiovascular diseases [1,2]. About one-third of all cancer deaths could be avoided through appropriate dietary modification by increasing the consumption of fruits, vegetables and whole grains [3].

Phenolics, which play a crucial role in determining the sensory and nutritional quality of fresh apples, are an essential part of the human diet and are of considerable interest due to their antioxidant properties. Among the polyphenolic compounds found in apples, more than $50 \%$ are procyanidins (tannins), responsible for the pungent and bitter taste of the fruit. The rest of the biologically active structures are phenolic acids, dihydrochalcones, quercetin glycosides, and anthocyanins. The main phenolic acid in apples is chlorogenic acid and among dihydrochalcones dominates phloridzin and phloretin-xyloglucoside $[4,5]$. 
Total phenolic content of plant foods varies according to the extrinsic factors, such as geographic differences and different climate features, parts of plants analyzed, harvesting time, extraction and determination methods [6]. Besides, phenolic contents of plants depend on a number of intrinsic factors, such as genus, species and cultivars [7].

Apples have a relatively long storage life comparing with other fruits varieties. However, the main problem of apple storage is the fruit firmness. Fruit ripening is accompanied by softening, which is one of the most important determinants of fruit quality and consumer acceptability. Softening is generally considered an undesirable ripening process in apple fruit, as firmer apples tend to be juicier, crisper, crunchier and less mealy than softer ones [8]. One way of extending storage life of fruit is to control ethylene production and perception.

1-Methylcyclopropene (1-MCP) is a synthetic cyclic olefin capable of inhibiting ethylene action. It acts in very low concentrations as a competitor of ethylene, blocking its access to the ethylene-binding receptors [9]. 1-MCP is now used commercially in many parts of the world as a postharvest tool to maintain the quality of numerous horticultural products [10].

Despite the growing interest in the use of 1-MCP-based technology, still little is known about its effects on the nutritional properties of apples. Because of the increased interest in apple phenolics in the diet, it is important to document and understand their metabolism during long-term storage. Phenolic metabolism is a complex process, as phenolics undergo constant turnover and degradation [11, 12].

The aim of this study was to evaluate the effect of the postharvest treatment by $1-\mathrm{MCP}$ and storage time on the apple quality. The effects of apple storage during 6 month on basic parameters such as dry weight, total soluble solids and titratable acidity, composition of phenolics, antioxidant activity and sensory evaluation were studied to evaluate the fruit composition, quality, sensory profile and potential applicability of long-time stored apples for further processing.

\section{Experimentals}

\section{Chemicals}

DPPH (1,1-diphenyl-2-picrylhydrazyl radical), ABTS (2,2'-azinobis-(3-ethylbenzothiazoline-6-sulfonic acid), Trolox (6-hydroxy-2,5,7,8-tetramethylchroman-2-carboxylic acid), TPTZ (2,4,6-tri(2-pyridyl)-s-triazine), acetic acid, phloroglucinol and methanol were purchased from Sigma-Aldrich (Steinheim, Germany). (-)-Epicatechin, $(+)$-catechin, chlorogenic acid, phloretin $2^{\prime}$ - $O$-glucoside, quercetin-3-O-glucoside and procyanidins $\mathrm{B}_{1}, \mathrm{~B}_{2}, \mathrm{C}_{1}$ were purchased from Extrasynthese (Lyon, France). Acetonitrile and ascorbic acid were from Merck (Darmstadt, Germany).

Plant material

Apples of 'Idared' and 'Shampion' cvs (Malus domestica Borkh.) were used for the experiment. 'Shampion' apples were harvested from 15-year-old trees grown on M.26 rootstock and planted with $4 \mathrm{~m} \times 1.5 \mathrm{~m}$ density in the orchard located in in Ostrowiec, near Lowicz-central Poland $\left(52^{\circ} 09^{\prime} 36,2880^{\prime \prime} \mathrm{N} \quad 20^{\circ} 03^{\prime} 22,5720^{\prime \prime} \mathrm{E}\right)$. 'Idared' apples were harvested from 13-year-old trees grown on $\mathrm{P}$ 60 rootstock and planted with $3.5 \mathrm{~m} \mathrm{x} 1.5 \mathrm{~m}$ density in the orchard located in Kozietuly in Grójec region $\left(51^{\circ} 45^{\prime} 04^{\prime \prime} \mathrm{N}\right.$ $20^{\circ} 45^{\prime} 50^{\prime \prime} \mathrm{E}$ ). In both orchards irrigation, training, mineral nutrition and orchard management system are used according to standard commercial practice. Crop protection programmes are applied in conformity with integrated fruit production rules. Fruits were harvested at optimum ripening stage recommended for long-term storage (based on internal ethylene concentration and starch index). After harvest, fruits were transported to Fruit Storage Laboratory of the Research Institute of Horticulture (formerly Research Institute of Pomology and Floriculture) in Skierniewice and were divided into two groups. Both groups were placed in cold room (temperature $+2{ }^{\circ} \mathrm{C}$ ). On sixth day, one group of apples were treated with 1-methylocyclopropene for $24 \mathrm{~h}$ at $2{ }^{\circ} \mathrm{C}$ at the commercial rate (1-MCP, $625 \mathrm{ppb}$, SmartFresh $0.14 \%$, AgroFresh Inc., wholly owned subsidiary of DOW Chemicals Company) according to Hoang et al. [13]. Then, both groups of fruits were stored for 2, 4 and 6 months under normal atmosphere at $2{ }^{\circ} \mathrm{C}$ with relative humidity ca $90 \%$.

Identification of polyphenols by the ultraperformance liquid chromatography-mass spectrometry (UPLC-MS) method.

Identification of apple polyphenols was determined using the ACQUITY Ultra Performance LC ${ }^{\text {TM }}$ system with Micromass G2 Q-Tof Micromass equipped with an electrospray ionization (ESI) as described previously by KolniakOstek et al. [14].

\section{HPLC analysis of polyphenols}

Polyphenolic compounds and polymer procyanidins by phloroglucinol method were determined using the HPLC method described previously by Wojdyło et al. [15].

Analysis of antioxidant activity

The total antioxidant potential of samples was determined using a ferric reducing ability of plasma (FRAP) assay by Benzie et al. [16] as a measure of antioxidant power. The 
DPPH radical scavenging activity of samples was determined according to the method of Yen et al. [17]. The ABTS $^{+}$activity of samples was determined according to the method of Re et al. [18]. For all analysis, portions $(0.5 \mathrm{~g})$ of freeze-dried apples were precisely measured into vials and mixed with methanol $(80 \%)$ acidified with HCL $(1 \mathrm{ml} / \mathrm{l})$. Standard curve was prepared using different concentrations of Trolox. All determinations were performed in triplicates using a Shimadzu UV-2401 PC spectrophotometer (Kyoto, Japan). The results were corrected for dilution and expressed in $\mu \mathrm{M}$ Trolox $/ \mathrm{kg}$.

\section{Dry matter}

The dry matter of fresh apples was performed by gravimetric method, according to Polish Norm [19]. Fresh apple samples $(1.5 \mathrm{~g})$ were precisely measured and dried at $70{ }^{\circ} \mathrm{C}$ in a vacuum $(3 \mathrm{kPa})$, until a constant weight. The measurements were performed in triplicate and expressed as $\mathrm{g}$ of dry weight $/ 100 \mathrm{~g}$ of fresh matter.

\section{Total soluble solids}

Percentage of total soluble solids was determined refractometrically, using electronic Pocket Refractometer PAL-1 (Atago, USA). The measurements were taken in triplicate and expressed in $\mathrm{g}$ of soluble solids/100 $\mathrm{g}$ of fresh matter.

\section{Titrable acidity}

Titratable acidity of samples was determined by using a pH meter (IQ's Scientific Instruments), according to Polish Norm [20]. The chopped apples were transferred to a volumetric flask $(100 \mathrm{ml})$ and filled with water. Prepared samples were boiled and filtered after cooling down. About $10 \mathrm{ml}$ of obtained filtrate was titrated with $\mathrm{NaOH}$ $\left(0.1 \mathrm{~mol} \mathrm{~L}^{-1}\right)$ up to $\mathrm{pH}$ 8.1. The measurements were performed in triplicate and expressed in $\mathrm{g}$ of malic acid/100 $\mathrm{g}$ of fresh matter.

\section{Sensory analysis}

The quality of the fresh and stored apples was evaluated using a profiling method. The expert panel consisted of 15 persons, recruited from the staff of the Research Institute of Horticulture, trained and having extensive experience in performing sensory assessment of horticultural products. Before successive seasons the panelists participated in special training sessions, where particular attributes' definitions were discussed and clarified. For particular sessions, 10 available experts were invited. Sensory testing laboratory fulfilled the general requirements of the relevant ISO 8589:1998 [21] standard for sensory testing conditions.
Each test booth was illuminated with white light $(6,500 \mathrm{~K})$ and equipped with a computerized system for data acquisition (Analsens v.4 software, Caret Systemy Cyfrowe i Oprogramowanie Sp. z o.o., Gdańsk, Poland). During one session, two combinations of fresh, and four combinations of stored apples were tested. Fruits were served peeled and placed in small plastic containers, which were covered for $5 \mathrm{~min}$ before sample presentation, to induce the aroma head space accumulation. Samples assigned with 3-digit codes were presented randomly. The experts assessed qualitative traits using an unstructured 100-mm linear scale anchored at their ends with relevant word description. The results were transposed into a $0-10$ point scale, where ' 0 ' denoted lack of a given trait or a bad level, while ' 10 ' indicated an intensive sensation or a high quality. Other evaluated attributes included: ripe apple aroma, hardness, crispness, juiciness, overall texture, taste (sweet, sour, overall score) and the overall quality defined as the overall sensory impression of balance and harmony of all attributes and their interactions.

\section{Fruit firmness}

Fruit firmness was measured using at least 20 fruits, on the opposite sides of fruit (blushed and unblushed) using an EPT-1R pressure tester (Lake City Technical Products, Canada), equipped with $11.1 \mathrm{~mm}$ tip.

Statistical analysis

Results were given as mean \pm standard deviation of three independent determinations. All statistical analyses were performed with Statistica version 9.1 (StatSoft, Poland). One-way analysis of variance (ANOVA) by Duncan's test was used to compare the means. Differences were considered to be significant at $P=0.05$.

\section{Results and discussion}

Effect of 1-MCP on the basic parameters of fresh apples

The effect of postharvest treatment with 1-MCP and longtime storage of apples, on the total soluble solids, dry matter and titrable acidity was presented in Table 1 . Storage of apples has increased the dry matter in all samples. In 'Idared' cv., dry matter varied from $15.6 \mathrm{~g} / 100 \mathrm{~g}$ after 6-month storage for untreated fruits to $15.4 \mathrm{~g} / 100 \mathrm{~g}$ after 1-MCP treatment. In 'Shampion' cv., after 6-month storage, apple dry matter increased from $14.7 \mathrm{~g} / 100 \mathrm{~g}$ in fresh fruits up to $17.0 \mathrm{~g} / 100 \mathrm{~g}$ in control sample and up to $16.0 \mathrm{~g} / 100 \mathrm{~g}$ after 1-MCP treatment. Generally, after long-time storage, dry weight of apples treated by 1-MCP was about $3.5 \%$ lower, compared with untreated fruits. 
Table 1 The effect of long-time storage in control and after postharvest treatment by 1-MCP on the quality of apples
Values are mean \pm standard deviation, $n=3$; mean values within a verses with different letters $(\mathrm{a}, \mathrm{b}, \mathrm{c} . .$. are significantly different at $P<0.05$

* Expressed as malic acid

\begin{tabular}{|c|c|c|c|}
\hline & Dry matter $(\mathrm{g} / 100 \mathrm{~g})$ & $\begin{array}{l}\text { Total soluble solids } \\
(\mathrm{g} / 100 \mathrm{~g})\end{array}$ & $\begin{array}{l}\text { Tritatable acidity } \\
(\mathrm{g} / 100 \mathrm{~g})^{*}\end{array}$ \\
\hline \multicolumn{4}{|l|}{ Idared (m) } \\
\hline \multicolumn{4}{|l|}{0} \\
\hline Harvest & $14.9 \pm 0.1 \mathrm{e}$ & $14.0 \pm 0.0 \mathrm{~d}$ & $0.57 \pm 0.0 \mathrm{a}$ \\
\hline \multicolumn{4}{|l|}{2} \\
\hline CONTROL & $15.4 \pm 0.0 \mathrm{~d}$ & $13.4 \pm 0.0 \mathrm{f}$ & $0.51 \pm 0.1 \mathrm{~b}$ \\
\hline 1-MCP & $15.3 \pm 0.2 \mathrm{~d}$ & $13.7 \pm 0.2 \mathrm{e}$ & $0.52 \pm 0.0 \mathrm{~b}$ \\
\hline \multicolumn{4}{|l|}{4} \\
\hline CONTROL & $15.4 \pm 0.2 \mathrm{~d}$ & $13.2 \pm 0.1 \mathrm{~g}$ & $0.38 \pm 0.0 \mathrm{~d}$ \\
\hline 1-MCP & $15.2 \pm 0.1 \mathrm{~d}$ & $12.9 \pm 0.0 \mathrm{i}$ & $0.41 \pm 0.0 \mathrm{c}$ \\
\hline \multicolumn{4}{|l|}{6} \\
\hline CONTROL & $15.6 \pm 0.3 \mathrm{~d}$ & $12.9 \pm 0.2 \mathrm{i}$ & $0.33 \pm 0.1 \mathrm{e}$ \\
\hline 1-MCP & $15.4 \pm 0.0 \mathrm{c}$ & $12.2 \pm 0.0 \mathrm{j}$ & $0.38 \pm 0.1 \mathrm{~d}$ \\
\hline \multicolumn{4}{|l|}{ Shampion (m) } \\
\hline \multicolumn{4}{|l|}{0} \\
\hline Harvest & $14.7 \pm 0.2 \mathrm{f}$ & $15.0 \pm 0.2 \mathrm{a}$ & $0.29 \pm 0.0 \mathrm{f}$ \\
\hline \multicolumn{4}{|l|}{2} \\
\hline CONTROL & $16.4 \pm 0.1 \mathrm{~b}$ & $14.9 \pm 0.2 \mathrm{ab}$ & $0.26 \pm 0.1 \mathrm{~g}$ \\
\hline 1-MCP & $15.5 \pm 0.1 \mathrm{~cd}$ & $15.2 \pm 0.1 \mathrm{a}$ & $0.19 \pm 0.1 \mathrm{~h}$ \\
\hline \multicolumn{4}{|l|}{4} \\
\hline CONTROL & $16.9 \pm 0.1 \mathrm{a}$ & $14.8 \pm 0.1 \mathrm{~b}$ & $0.20 \pm 0.1 \mathrm{~h}$ \\
\hline 1-MCP & $15.6 \pm 0.0 \mathrm{c}$ & $14.6 \pm 0.2 \mathrm{c}$ & $0.16 \pm 0.0 \mathrm{i}$ \\
\hline \multicolumn{4}{|l|}{6} \\
\hline CONTROL & $17.0 \pm 0.1 \mathrm{a}$ & $13.8 \pm 0.1 \mathrm{e}$ & $0.15 \pm 0.0 \mathrm{ij}$ \\
\hline 1-MCP & $16.0 \pm 0.0 \mathrm{~b}$ & $13.1 \pm 0.1 \mathrm{~h}$ & $0.14 \pm 0.0 \mathrm{j}$ \\
\hline
\end{tabular}

After long-time storage of apples, decrease of total soluble solids was observed. In 'Idared' cv., total soluble solids varied from $12.9 \mathrm{~g} / 100 \mathrm{~g}$ after 6-month storage for untreated fruits to $12.2 \mathrm{~g} / 100 \mathrm{~g}$ after $1-\mathrm{MCP}$ treatment. In 'Shampion' cv., after 6-month storage, total soluble solids decreased to $13.8 \mathrm{~g} / 100 \mathrm{~g}$ in control samples and to $13.1 \mathrm{~g} / 100 \mathrm{~g}$ after $1-\mathrm{MCP}$ treatment. Generally, after 1-MCP treatment, total soluble solids of apple were about $5.0 \%$ lower compared with untreated fruits. However, still, total soluble solids are much higher than the minimum requirements given by AIJN [X] for single-strength juice and do not restrict its processing into juice.

Long-time storage of apples resulted in a lower titratable acidity in all samples. In 'Idared' cv. after 6-month storage, titratable acidity decreased from $0.57 \mathrm{~g} / 100 \mathrm{~g}$ in fresh samples to $0.33 \mathrm{~g} / 100 \mathrm{~g}$ in control samples and 0.38 $\mathrm{g} / 100 \mathrm{~g}$ after 1-MCP treatment. In 'Shampion' cv., after 1-MCP treatment, apple acidity decreased to $0.14 \mathrm{~g} / 100$ and to $0.15 \mathrm{~g} / 100 \mathrm{~g}$. This is below the minimum content for authentic juice which is $0.4 \mathrm{~g} / \mathrm{l}[\mathrm{X}]$ and indicates stored 'Shampion' fruits should be mixed or processed with cultivars with higher acidity.

Scientific data indicate that the composition and content of chemical compounds in fruits mainly depends on the species and variety [22]. The degree of ripeness of fruit has a significant influence on the content of sugars, minerals and acids. The sugar content in fully ripe apples is high due to complete hydrolysis of starch. Then, during storage, sugars content begins to decrease, as they are consumed in respiration process [23].

During ripening on the tree, the organic acid content in apples increases, reaches a maximum for a few days before harvest and then slightly decreases. However, acid content during storage has been gradually declining. It is thought that part of them, in addition to sugars, may be consumed in the process of respiration. Storage leads to softening of fruits, which is mediated by loss of cell-to-cell adhesion. Tissue from soft fruits has rounded cells, bigger cell separation and larger intercellular spaces [24, 25]. Analyses of pectin fractions have shown that apple softening is usually associated with the increased content of water-soluble pectin and reduced galactose and arabinose residues. A number of cell-wall-modifying enzymes that have been found in ripening apples may cause softening. The enzyme originally considered responsible for pectin solubilization, and therefore, softening was polygalacturonase (PG), with activities of both exo-PG and endo-PG detected in ripening apples [26]. Direct measurements of turgor showed that 
Table 2 Retention time $\left(R_{\mathrm{t}}\right), \lambda_{\max }$ and MS/MS fragmentation data of major phenolics detected in analyzed apples

\begin{tabular}{|c|c|c|c|c|c|}
\hline Group of polyphenols & $R_{\mathrm{t}}(\min )$ & $\lambda_{\max }(\mathrm{nm})$ & Compound & {$[\mathrm{M}-\mathrm{H}]^{-}(\mathrm{m} / \mathrm{z})$} & $\mathrm{MS} / \mathrm{MS}(\mathrm{m} / \mathrm{z})$ \\
\hline \multirow[t]{3}{*}{ Hydroxycinnamic acids } & 3.72 & 320 & Chlorogenic acid & 353 & 191 \\
\hline & 5.05 & 320 & Cryptochlorogenic acid & 353 & 137 \\
\hline & 5.71 & 305 & $p$-Coumaryloquinic acid & 337 & 163 \\
\hline \multirow[t]{5}{*}{ Flavanols and procyanidins } & 2.47 & 275 & Procyanidin B1 & 578 & 289 \\
\hline & 2.81 & 280 & $(+)-$ Catechin & 289 & 245 \\
\hline & 5.47 & 275 & Procyanidin B2 & 578 & 289 \\
\hline & 5.90 & 280 & (-)-Epicatechin & 289 & 245 \\
\hline & 5.98 & 280 & Procyanidin $\mathrm{C} 1$ & 866 & 577,289 \\
\hline \multirow[t]{2}{*}{ Dihydrochalcones } & 6.99 & 285 & Phloretin $2^{\prime}-O$-xyloglucose & 567 & 273 \\
\hline & 8.06 & 285 & Phloretin $2^{\prime}$ - $O$-glucose & 435 & 273 \\
\hline \multirow[t]{5}{*}{ Flavonols } & 6.23 & 355 & Quercetin-3-O-galactoside & 463 & 301 \\
\hline & 6.56 & 350 & Quercetin-3-O-glucoside & 463 & 301 \\
\hline & 6.69 & 350 & Quercetin-3- $O$-xyloside & 433 & 301 \\
\hline & 7.12 & 355 & Quercetin-3-O-arabinoside & 433 & 301 \\
\hline & 7.90 & 345 & Quercetin-3-O-rhamnoside & 447 & 301 \\
\hline
\end{tabular}

cell turgor decreased in four apple cultivars during storage. There was a positive association between cell turgor and firmness after 6 months at $0-2{ }^{\circ} \mathrm{C}$ for cultivars with different softening rates. The dry matter content in fruit is variable and depends, i.e., on the type of soil, fertilization and the conditions prevailing during the growing season [27].

Qualitative analysis of polyphenolic compounds

As an initial step, apple samples were analyzed by LC-MS QTof and HPLC-DAD systems. Fifteen different polyphenolic compounds were identified as function of their retention times compared with the standard compounds in HPLC analyses and as function of their mass fragmentation compared with those of the standard compound during LC-MS QTof analyses. Qualitative analyses obtained by LC-MS QTof methods and by HPLC are summarized in Tables 2 and 3. Three hydroxycinnamates were detected: $p$-coumaroylquinic acid, chlorogenic acid and cryptochlorogenic acid. The compound that had a $[\mathrm{M}-\mathrm{H}]^{-}$at $m / z 337$ was identified as $p$-coumaroylquinic acid. Chlorogenic acid and cryptochlorogenic acid have a characteristic mass spectral data as is produced on $[\mathrm{M}-\mathrm{H}]^{-}$at $\mathrm{m} / \mathrm{z}, 353$ and the fragmentation of the negatively charged molecular ion $\left([\mathrm{M}-\mathrm{H}]^{-}\right)$at $\mathrm{m} / z, 191$ and 137 , respectively. Five flavan3-ols were detected: $(+)$-catechin, $(-)$-epicatechin and procyanidins $\mathrm{B}_{1}, \mathrm{~B}_{2}$ and $\mathrm{C}_{1}$. In the presence retention time $\left(R_{t}\right)$ at $2.81 \mathrm{~min}, \lambda_{\max }$ for $280 \mathrm{~nm}$ was identified as $(+)$-catechin with the fragmentation of the negatively charged molecular ion $\left([\mathrm{M}-\mathrm{H}]^{-}\right)$at $m / z$ 289. Procyanidin $\mathrm{B}_{1}$ and $\mathrm{B}_{2}\left(\lambda_{\max }\right)$ $275 \mathrm{~nm}$ had a $[\mathrm{M}-\mathrm{H}]^{-}$at $\mathrm{m} / \mathrm{z}, 578$, but the retention time for procyanidin $\mathrm{B}_{1}$ was $R_{\mathrm{t}}$ at 2.47 min and for $\mathrm{B}_{2}$ was $\left(R_{\mathrm{t}}\right)$ $5.47 \mathrm{~min}$. The compound with $\left(R_{\mathrm{t}}\right) 5.98 \mathrm{~min}, \lambda_{\max } 280 \mathrm{~nm}$ that had the highest MW, with a $[\mathrm{M}-\mathrm{H}]^{-}$at $\mathrm{m} / \mathrm{z} 866$ is procyanidin $\mathrm{C}_{1}$. The compound that had the $R_{\mathrm{t}}=5.90$ min and $\lambda_{\max } 280 \mathrm{~nm}$ was identified as (-)-epicatechin. Dihydrochalcones were detected: phloretin $2^{\prime}-O$-xyloglucoside and phloretin $2^{\prime}-O$-glucoside. The peak with a $[\mathrm{M}-\mathrm{H}]^{-}$at $\mathrm{m} / \mathrm{z}$ 567 that had a $R_{\mathrm{t}=}=6.99$ and $\lambda_{\max } 285 \mathrm{~nm}$ is phloretin- $2^{\prime}$ $O$-xyloglucoside. The peak at $R_{\mathrm{t}}=8.06 \mathrm{~min}, \lambda_{\max } 285 \mathrm{~nm}$ produced a $[\mathrm{M}-\mathrm{H}]^{-}$at $\mathrm{m} / \mathrm{z}, 435$ is the phloretin $2^{\prime}-O$-glucoside. Flavonols were detected as quercetin-3-O-galactoside, -3-O-glucoside, -3-O-arabinoside, -3-O-xyloside and -3-O-rhamnoside. Peaks with $R_{\mathrm{t}}=6.23$ and $6.56 \mathrm{~min}$ had $\lambda_{\max }$ values of 355 and 350 , respectively. Both had a $[\mathrm{M}-\mathrm{H}]^{-}$at $\mathrm{m} / z$ 463, and fragmentation yielded a quercetin ion at $\mathrm{m} / \mathrm{z} 301$. This fragmentation pattern and $\lambda_{\max }$ demonstrates that this peaks are quercetin-3-O-galactoside and -3-O-glucoside, respectively. A similar situation was found for quercetin-3-O-xyloside and -3-O-arabinoside that brought the same $\mathrm{m} / \mathrm{z} 433$ but different $R_{\mathrm{t}}=6.69$ and $7.12 \mathrm{~min}$, respectively. The compound at $R_{\mathrm{t}}=7.90 \mathrm{~min}$, $\lambda_{\max } 345 \mathrm{~nm}$ that produced a $[\mathrm{M}-\mathrm{H}]^{-}$at $\mathrm{m} / z 447$ and a fragment at $\mathrm{m} / \mathrm{z} 301$ was identified as quercetin-3-O-rhamnoside. The obtained results were typical for apple polyphenols and in agreement with previously published results $[28,29]$.

Effect of 1-MCP on phenolic compounds of apples

The composition and characterization of polyphenolic compounds in fresh apples and after storage is summarized in Tables 2 and 3. The major polyphenolic groups in apples were hydroxycinnamic acids, flavan-3-ols/procyanidins, flavonols, dihydrochalcones and anthocyanins. The total phenolics determined by HPLC in fresh apples ranged from 
Table 3 The effect of long-time storage in control and after postharvest treatment by 1-MCP on the concentration of phenolic compounds (mg/ $\mathrm{kg}$ ) in apples

\begin{tabular}{|c|c|c|c|c|c|c|c|c|c|}
\hline & ChA & $\mathrm{CA}$ & $p$-CA & $\mathrm{E}$ & PB2 & $\mathrm{PC} 1$ & $\mathrm{C}$ & PB1 & PXylo \\
\hline \multicolumn{10}{|l|}{ Idared (m) } \\
\hline \multicolumn{10}{|l|}{0} \\
\hline Harvest & $78.9 \pm 3.2 \mathrm{f}$ & $2.9 \pm 0.2 \mathrm{a}$ & $11.7 \pm 0.2 \mathrm{a}$ & $74.4 \pm 1.3 \mathrm{a}$ & $163.3 \pm 4.8 \mathrm{a}$ & $44.0 \pm 1.8 \mathrm{a}$ & $10.8 \pm 0.8 \mathrm{~d}$ & $16.7 \pm 0.9 \mathrm{f}$ & $17.2 \pm 0.4 \mathrm{a}$ \\
\hline \multicolumn{10}{|l|}{2} \\
\hline CONTROL & $45.5 \pm 1.8 \mathrm{~h}$ & $2.1 \pm 0.3 \mathrm{e}$ & $10.5 \pm 0.3 b$ & $62.2 \pm 2.2 b$ & $120.0 \pm 3.2 \mathrm{~b}$ & $37.7 \pm 4.2 \mathrm{~b}$ & $9.2 \pm 0.3 \mathrm{e}$ & $14.7 \pm 1.1 \mathrm{~g}$ & $14.6 \pm 0.2 b$ \\
\hline 1-MCP & $49.6 \pm 2.6 \mathrm{~g}$ & $2.0 \pm 0.1 \mathrm{f}$ & $8.6 \pm 0.2 \mathrm{c}$ & $57.1 \pm 1.8 \mathrm{~d}$ & $91.4 \pm 2.5 \mathrm{e}$ & $23.4 \pm 3.6 \mathrm{~g}$ & $7.7 \pm 0.8 \mathrm{~g}$ & $12.8 \pm 0.7 \mathrm{i}$ & $12.7 \pm 0.6 \mathrm{c}$ \\
\hline \multicolumn{10}{|l|}{4} \\
\hline CONTROL & $34.1 \pm 3.3 \mathrm{i}$ & $0.9 \pm 0.0 \mathrm{k}$ & $7.2 \pm 0.1 \mathrm{~d}$ & $59.0 \pm 1.7 \mathrm{c}$ & $116.7 \pm 2.0 \mathrm{c}$ & $30.1 \pm 1.4 \mathrm{c}$ & $8.4 \pm 0.2 \mathrm{f}$ & $13.5 \pm 1.3 \mathrm{~h}$ & $5.4 \pm 0.1 \mathrm{e}$ \\
\hline 1-MCP & $44.9 \pm 1.4 \mathrm{~h}$ & $1.4 \pm 0.1 \mathrm{~h}$ & $8.6 \pm 0.1 \mathrm{c}$ & $56.3 \pm 2.3 \mathrm{e}$ & $90.3 \pm 4.1 \mathrm{e}$ & $21.9 \pm 2.5 \mathrm{~h}$ & $7.5 \pm 0.1 \mathrm{~g}$ & $12.7 \pm 0.8 \mathrm{i}$ & $12.6 \pm 0.4 \mathrm{c}$ \\
\hline \multicolumn{10}{|l|}{6} \\
\hline CONTROL & $33.4 \pm 2.2 \mathrm{j}$ & $0.4 \pm 0.01$ & $5.2 \pm 0.2 \mathrm{f}$ & $52.6 \pm 3.6 \mathrm{~g}$ & $109.4 \pm 4.6 \mathrm{~d}$ & $29.4 \pm 2.0 \mathrm{~d}$ & $5.1 \pm 0.1 \mathrm{~h}$ & $12.5 \pm 0.8 \mathrm{j}$ & $4.8 \pm 0.0 \mathrm{f}$ \\
\hline 1-MCP & $32.9 \pm 2.5 \mathrm{k}$ & $1.3 \pm 0.2 \mathrm{i}$ & $5.8 \pm 0.0 \mathrm{f}$ & $47.8 \pm 2.8 \mathrm{~h}$ & $88.6 \pm 3.9 \mathrm{f}$ & $23.5 \pm 3.2 \mathrm{~g}$ & $7.4 \pm 0.1 \mathrm{~g}$ & $12.5 \pm 1.2 \mathrm{j}$ & $11.4 \pm 0.5 \mathrm{~d}$ \\
\hline \multicolumn{10}{|l|}{0} \\
\hline Harvest & $152.5 \pm 4.6 \mathrm{a}$ & $2.7 \pm 0.3 b$ & $7.1 \pm 0.2 \mathrm{~d}$ & $58.9 \pm 4.0 \mathrm{c}$ & $86.7 \pm 2.7 \mathrm{~g}$ & $30.4 \pm 2.1 \mathrm{c}$ & $13.4 \pm 0.2 \mathrm{a}$ & $20.3 \pm 0.9 \mathrm{a}$ & $2.3 \pm 0.1 \mathrm{~g}$ \\
\hline \multicolumn{10}{|l|}{2} \\
\hline CONTROL & $149.3 \pm 4.1 \mathrm{~b}$ & $2.6 \pm 0.2 \mathrm{c}$ & $6.2 \pm 0.3 \mathrm{e}$ & $55.7 \pm 3.7 \mathrm{f}$ & $79.9 \pm 2.3 \mathrm{i}$ & $29.3 \pm 2.3 \mathrm{~d}$ & $12.4 \pm 0.1 \mathrm{~b}$ & $18.2 \pm 0.6 \mathrm{~d}$ & $1.9 \pm 0.0 \mathrm{~g}$ \\
\hline 1-MCP & $152.5 \pm 3.9 \mathrm{a}$ & $2.5 \pm 0.4 \mathrm{~d}$ & $7.0 \pm 0.2 \mathrm{~d}$ & $58.5 \pm 2.2 \mathrm{c}$ & $86.5 \pm 1.6 \mathrm{~g}$ & $30.4 \pm 1.4 \mathrm{c}$ & $13.2 \pm 0.3 \mathrm{a}$ & $20.1 \pm 0.9 b$ & $2.0 \pm 0.1 \mathrm{~g}$ \\
\hline \multicolumn{10}{|l|}{4} \\
\hline CONTROL & $139.8 \pm 2.8 \mathrm{c}$ & $2.1 \pm 0.0 \mathrm{e}$ & $5.3 \pm 0.1 \mathrm{~g}$ & $39.7 \pm 1.3 \mathrm{j}$ & $69.9 \pm 3.0 \mathrm{k}$ & $20.4 \pm 0.9 \mathrm{i}$ & $9.9 \pm 0.1 \mathrm{e}$ & $15.0 \pm 0.5 \mathrm{~g}$ & $1.2 \pm 0.1 \mathrm{~h}$ \\
\hline 1-MCP & $132.9 \pm 1.7 \mathrm{~d}$ & $1.6 \pm 0.1 \mathrm{~g}$ & $6.3 \pm 0.0 \mathrm{e}$ & $41.6 \pm 3.4 \mathrm{i}$ & $82.1 \pm 3.8 \mathrm{~h}$ & $28.8 \pm 1.1 \mathrm{e}$ & $11.2 \pm 0.0 \mathrm{c}$ & $19.2 \pm 1.0 \mathrm{c}$ & $1.5 \pm 0.0 \mathrm{~h}$ \\
\hline \multicolumn{10}{|l|}{6} \\
\hline CONTROL & $126.8 \pm 4.6 \mathrm{f}$ & $1.2 \pm 0.0 \mathrm{j}$ & $3.2 \pm 0.1 \mathrm{i}$ & $36.1 \pm 2.51$ & $63.8 \pm 2.71$ & $15.8 \pm 1.9 \mathrm{j}$ & $8.1 \pm 0.2 \mathrm{f}$ & $13.2 \pm 0.3 \mathrm{~h}$ & $0.5 \pm 0.0 \mathrm{i}$ \\
\hline \multirow[t]{2}{*}{ 1-MCP } & $130.0 \pm 3.0 \mathrm{e}$ & $1.4 \pm 0.0 \mathrm{~h}$ & $4.6 \pm 0.1 \mathrm{~h}$ & $38.3 \pm 1.0 \mathrm{k}$ & $75.8 \pm 4.1 \mathrm{j}$ & $26.2 \pm 2.0 \mathrm{f}$ & $10.4 \pm 0.3 \mathrm{~d}$ & $17.2 \pm 0.6 \mathrm{e}$ & $1.1 \pm 0.1 \mathrm{~h}$ \\
\hline & Pgluco & Qgala & Qgluco & Qara & Qxylo & Qrhamno & PP & \multicolumn{2}{|c|}{ Total } \\
\hline
\end{tabular}

Idared $(\mathrm{m})$

0

\begin{tabular}{|c|c|c|c|c|c|c|c|c|}
\hline Harvest & $19.2 \pm 1.0 \mathrm{a}$ & $6.5 \pm 0.7 \mathrm{c}$ & $1.5 \pm 0.3 \mathrm{a}$ & $4.8 \pm 0.3 \mathrm{~d}$ & $5.6 \pm 0.3 \mathrm{f}$ & $5.4 \pm 0.0 \mathrm{a}$ & $780.3 \pm 5.9 \mathrm{~d}$ & $1,243 \pm 9.9 \mathrm{c}$ \\
\hline \multicolumn{9}{|l|}{2} \\
\hline CONTROL & $17.5 \pm 0.8 b$ & $5.9 \pm 0.9 \mathrm{~d}$ & $1.2 \pm 0.1 \mathrm{a}$ & $3.9 \pm 0.2 \mathrm{f}$ & $4.9 \pm 0.2 \mathrm{~g}$ & $4.6 \pm 0.3 \mathrm{e}$ & $832.5 \pm 8.6 \mathrm{c}$ & $1,187 \pm 8.3 \mathrm{~d}$ \\
\hline 1-MCP & $14.0 \pm 0.6 \mathrm{~d}$ & $4.7 \pm 0.3 \mathrm{e}$ & $1.3 \pm 0.2 \mathrm{a}$ & $4.3 \pm 0.6 \mathrm{e}$ & $4.6 \pm 0.2 \mathrm{~h}$ & $4.7 \pm 0.2 \mathrm{~d}$ & $667.3 \pm 7.5 \mathrm{i}$ & $966 . \pm 9.8 \mathrm{~h}$ \\
\hline \multicolumn{9}{|l|}{4} \\
\hline CONTROL & $15.6 \pm 0.1 \mathrm{c}$ & $4.4 \pm 0.6 \mathrm{e}$ & $0.9 \pm 0.0 \mathrm{~b}$ & $3.7 \pm 0.1 \mathrm{f}$ & $4.0 \pm 0.0 \mathrm{j}$ & $3.7 \pm 0.1 \mathrm{i}$ & $710.1 \pm 9.1 \mathrm{~g}$ & $1,017 \pm 10.2 \mathrm{~g}$ \\
\hline 1-MCP & $13.3 \pm 0.7 \mathrm{e}$ & $4.7 \pm 0.2 \mathrm{e}$ & $1.2 \pm 0.0 \mathrm{a}$ & $4.3 \pm 0.0 \mathrm{e}$ & $4.4 \pm 0.1 \mathrm{i}$ & $4.9 \pm 0.1 \mathrm{~b}$ & $649.1 \pm 2.2 \mathrm{j}$ & $938 \pm 8.3 \mathrm{i}$ \\
\hline \multicolumn{9}{|l|}{6} \\
\hline CONTROL & $8.6 \pm 0.5 \mathrm{i}$ & $3.7 \pm 0.1 \mathrm{f}$ & $0.8 \pm 0.1 \mathrm{~b}$ & $3.9 \pm 0.2 \mathrm{f}$ & $4.4 \pm 0.0 \mathrm{i}$ & $3.3 \pm 0.3 \mathrm{k}$ & $689.4 \pm 6.1 \mathrm{~h}$ & $966 \pm 11.5 \mathrm{~h}$ \\
\hline 1-MCP & $9.8 \pm 0.6 \mathrm{~h}$ & $3.7 \pm 0.2 \mathrm{f}$ & $0.8 \pm 0.0 \mathrm{~b}$ & $2.7 \pm 0.1 \mathrm{~g}$ & $4.4 \pm 0.0 \mathrm{i}$ & $4.2 \pm 0.0 \mathrm{~h}$ & $629.1 \pm 7.8 \mathrm{k}$ & $885 \pm 10.9 \mathrm{j}$ \\
\hline \multicolumn{9}{|l|}{0} \\
\hline Harvest & $14.5 \pm 0.4 \mathrm{~d}$ & $8.9 \pm 0.5 \mathrm{a}$ & $0.8 \pm 0.1 \mathrm{~b}$ & $7.1 \pm 0.3 \mathrm{a}$ & $17.4 \pm 0.5 \mathrm{a}$ & $4.9 \pm 0.2 b$ & $1,008.0 \pm 9.2 \mathrm{a}$ & $1,435 \pm 12.8$ \\
\hline \multicolumn{9}{|l|}{2} \\
\hline CONTROL & $10.8 \pm 0.2 \mathrm{~g}$ & $6.7 \pm 0.3 \mathrm{c}$ & $0.5 \pm 0.0 \mathrm{c}$ & $6.7 \pm 0.2 b$ & $16.8 \pm 0.4 b$ & $4.8 \pm 0.3 \mathrm{c}$ & $873.6 \pm 4.8 b$ & $1,275 \pm 13.2 b$ \\
\hline 1-MCP & $14.4 \pm 0.7 \mathrm{~d}$ & $8.9 \pm 0.2 \mathrm{a}$ & $0.7 \pm 0.0 \mathrm{~b}$ & $7.0 \pm 0.2 \mathrm{a}$ & $17.2 \pm 0.1 \mathrm{a}$ & $4.8 \pm 0.0 \mathrm{c}$ & $1,007.4 \pm 9.9 \mathrm{a}$ & $1,433 \pm 10.7$ \\
\hline \multicolumn{9}{|l|}{4} \\
\hline CONTROL & $8.9 \pm 0.1 \mathrm{i}$ & $4.3 \pm 0.3 \mathrm{e}$ & $0.3 \pm 0.0 \mathrm{~d}$ & $5.6 \pm 0.0 \mathrm{c}$ & $11.7 \pm 0.0 \mathrm{~d}$ & $4.7 \pm 0.1 \mathrm{~d}$ & $762.7 \pm 7.5 \mathrm{e}$ & $1,101 \pm 11.6 \mathrm{e}$ \\
\hline 1-MCP & $12.9 \pm 0.3 \mathrm{e}$ & $7.8 \pm 0.0 \mathrm{~b}$ & $0.4 \pm 0.0 \mathrm{c}$ & $6.8 \pm 0.1 \mathrm{~b}$ & $15.8 \pm 0.5 b$ & $4.5 \pm 0.1 \mathrm{f}$ & $873.6 \pm 5.9 b$ & $1,247 \pm 8.8 \mathrm{c}$ \\
\hline \multicolumn{9}{|c|}{ 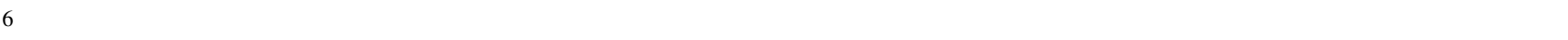 } \\
\hline CONTROL & $7.7 \pm 0.5 \mathrm{j}$ & $3.7 \pm 0.1 \mathrm{f}$ & $0.3 \pm 0.1 \mathrm{~d}$ & $4.7 \pm 0.1 \mathrm{~d}$ & $10.8 \pm 0.3 \mathrm{e}$ & $4.3 \pm 0.2 \mathrm{~g}$ & $753.0 \pm 4.3 \mathrm{f}$ & $1,053 \pm 12.4 \mathrm{f}$ \\
\hline 1-MCP & $11.7 \pm 0.6 \mathrm{f}$ & $6.3 \pm 0.3 \mathrm{c}$ & $0.4 \pm 0.0 \mathrm{c}$ & $6.8 \pm 0.0 \mathrm{~b}$ & $13.8 \pm 0.4 \mathrm{c}$ & $3.6 \pm 0.1 \mathrm{j}$ & $711.3 \pm 6.6 \mathrm{~g}$ & $1,059 \pm 13.6 \mathrm{f}$ \\
\hline
\end{tabular}

Values are mean \pm standard deviation, $n=3$; in columns, mean values with different letters $(\mathrm{a}, \mathrm{b}, \mathrm{c} \ldots$ ) are significantly different at $P<0.05$

ChA, chlorogenic acid; CA, cryptochlorogenic acid; $p$-CA, $p$-coumaryloquinic acid; E, (-)-epicatechin; PB2, procyanidin B2; PC1, procyanidin $\mathrm{C} 1$; C, (+)-catechin; PB1, procyanidin B2; PXylo, phloretin 2'-O-xyloglucose; Pgluco, phloretin 2'-O-glucose; Qgala, quercetin-3-O-galactoside; Qgluco, quercetin 3- $O$-glucoside; Qara, quercetin-3- $O$-arabinoside; Qxylo, quercetin-3- $O$-xyloside; Qrhamno, quercetin-3- $O$-rhamnoside; $\mathrm{PP}$, polimeric procyanidins; $\mathrm{m}$, month 
$1,243 \mathrm{mg} / \mathrm{kg}$ in 'Idared' cv. to $1,435 \mathrm{mg} / \mathrm{kg}$ in 'Shampion' cv. Types and amount of polyphenolic compounds detected in these apple cultivar studies were similar to previous studies $[4,15,30]$.

Analysis of nonstorage apples revealed a reasonably high content of polymeric procyanidins and flavan 3-ols, which represented 70.2 and $14.6 \%$ of total polyphenols in 'Idared' cv. nonstorage apples and 70.1 and $20.5 \%$ of total polyphenols in 'Shampion' cv. In fresh apples were also observed a high content of phenolic acids- $11.3 \%$ in 'Idared' cultivar and $6.2 \%$ in 'Shampion' cv.

According to the literature data (X) during storage, reduction of polyphenolic content has been observed $(P=0.05)$. In 'Shampion' cv., reduction of polyphenolic compounds was higher after 1-MCP treatment. In case of 'Idared' cv., different trend was observed-apples treated by 1 -MCP were characterized by a higher concentration of polyphenols. After 6-months of storage in 'Idared' cv., reduction of 26.2-26.6\% of polyphenolic content was observed. In 'Shampion' cv., decrease of polyphenols varied from 22.2 to $28.8 \%$.

In this study, phenolic compounds of analyzed cultivar of apples responded differently during storage with 1-MCP treatment. In 'Shampion' cv., hydroxycinnamic acids, flavan-3-ols, and procyanidins were significantly reduced after 1-MCP treatment. In 'Idared' cv., there was no such relationship. Decrease in the normal metabolism of phenolic compounds levels in fruits treated with 1-MCP may be caused by inhibition of ethylene production by 1-MCP. MacLean et al. [4] presented that the inhibition of polyphenols caused by 1-MCP depends on the fruit maturity-it was most dramatic in the early harvest maturity, less severe in the optimal harvest maturity and completely lost at the late harvest maturity fruits.

These results are similar to those obtained by Napolitano et al. [31]. After 4-month storage of 'Red Delicious' and 'Annurca' apples cv., they observed significant decrease of all polyphenolic classes concentrations. However, in apples 'Empire' and 'Golden Delicious,' they observed increase of total polyphenolics. Also Hoang, Golding and Wilkes [32] in 'Cripps Pink' apples after treated with 1-MCP and stored in normal and controlled atmosphere at $0{ }^{\circ} \mathrm{C}$ for up to 160 days observed that the level of phenolics decreased by $9 \%$ in the peel.

The polyphenol concentrations of apples depend strongly on the cultivar [33-35]. Apple phenolics are mainly localized in the peel and in the seeds. Progressive depolymerization of the major classes of cell wall polysaccharide, such as pectins, cellulose and hemicellulose during apple storage, can lead to the excessive softening, resulting in heavy postharvest losses. For example, the content of (-)-epicatechin and (+)-catechin may decrease during storage due to polymerization and re-arrangement of procyanidins during storage. Similar effect was observed previously for strawberry jams [36] and drying sour cherries [37].

Decrease of total polyphenols during cold storage could be due to the 1-MCP action. Ethylene stimulates activity of phenylalanine ammonia lyase, a key enzyme in biosynthesis of phenolic compounds $[38,39]$. The decrease of phenolic compounds observed in this study for 'Idared' and 'Shampion' cv. can be related to the inhibition of ethylene production by 1 -MCP.

\section{Effect of 1-MCP on antioxidant activity of apples}

The effect of long-time storage of apples on antioxidant activity was measured as free radical scavenging activity (ABTS and DPPH methods) and ferric reducing capacity by FRAP method (Table 4). In this study, the results of the ABTS, DPPH and FRAP methods were expressed in the same unit, i.e., $\mu \mathrm{Mol}$ of Trolox equivalent per kilogram of apple fresh matter.

The analysis revealed a statistically significant differences $(P=0.05)$ between apple cultivars. Among the fresh apples, DPPH antioxidant capacity varies from $3,818 \mu \mathrm{Mol} /$ $\mathrm{kg}$ in 'Idared' cv. to $4,299 \mu \mathrm{Mol} / \mathrm{kg}$ in 'Shampion' cv.; ABTS capacity varied from $1,883 \mu \mathrm{Mol} / \mathrm{kg}$ in 'Shampion' cv. apples to $1,923 \mu \mathrm{Mol} / \mathrm{kg}$ in 'Idared' cv.; FRAP antioxidant activity ranged $3,388 \mu \mathrm{Mol} / \mathrm{kg}$ in 'Shampion' cv. and $4,717 \mu \mathrm{Mol} / \mathrm{kg}$ in 'Idared' cv. The study showed that after storage, antioxidant capacity decreased - the lowest antioxidant properties were characterized by apples stored for a period of 6 months. In the case of 'Idared' cv., fruit treatment by 1-MCP limited the reduction in DPPH, ABTS and FRAP antioxidant capacity by average 8.5, 13.5 and $10 \%$, respectively. In case of 'Shampion' cv., stored apples after treatment by 1 -MCP have reduced DPPH activity by $25 \%$, ABTS activity by $17.5 \%$ and FRAP capacity by $2.5 \%$ in comparison with control apples (Table 4).

The differences in antioxidant activities between apple cultivars could be preliminarily attributed to their different contents and the type of polyphenols (Tables 2, 3). The data presented by Eberhardt et al. [33] and Salah et al. [40] show that the polymeric procyanidins have a high antioxidant activity. Also, Rice-Evans et al. [41] in their studies of antioxidant properties of polyphenolic compounds show that the compounds from the group of flavan-3-ols have strong antioxidative properties, while Horubała [42] argues that some polyphenols have antioxidant activity several times higher than ascorbic acid, such as quercetin is 4.7fold more active and tannins as much as 3-30-fold.

Decrease in antioxidant activity is associated with the process of oxidation of polyphenolic compounds, formation of complexes with other food ingredients or transition of active polyphenols forms into inactive compounds 
Table 4 The effect of long-time storage in control and after postharvest treatment by $1-\mathrm{MCP}$ on the antioxidant activity ( $\mu \mathrm{Mol}$ Trolox/ $\mathrm{kg}$ ) of apples

\begin{tabular}{|c|c|c|c|}
\hline & DPPH & ABTS & FRAP \\
\hline \multicolumn{4}{|l|}{ Idared (m) } \\
\hline \multicolumn{4}{|l|}{0} \\
\hline Harvest & $3,818 \pm 23 b$ & $1,923 \pm 25 \mathrm{a}$ & $4,718 \pm 56 \mathrm{a}$ \\
\hline \multicolumn{4}{|l|}{2} \\
\hline CONTROL & $3,216 \pm 34 \mathrm{e}$ & $1,297 \pm 13 \mathrm{~g}$ & $3,812 \pm 33 c$ \\
\hline 1-MCP & $3,720 \pm 26 b$ & $1,405 \pm 31 \mathrm{e}$ & $4,624 \pm 54 \mathrm{~b}$ \\
\hline \multicolumn{4}{|l|}{4} \\
\hline CONTROL & $3,065 \pm 18 \mathrm{~g}$ & $1,027 \pm 10 \mathrm{i}$ & $3,479 \pm 25 \mathrm{~d}$ \\
\hline 1-MCP & $3,135 \pm 31 \mathrm{f}$ & $1,156 \pm 25 \mathrm{~h}$ & $3,806 \pm 34 \mathrm{c}$ \\
\hline \multicolumn{4}{|l|}{6} \\
\hline CONTROL & $2,429 \pm 18 \mathrm{j}$ & $788 \pm 9 \mathrm{k}$ & $3,112 \pm 21 \mathrm{f}$ \\
\hline 1-MCP & $2,678 \pm 39 h$ & $998 \pm 29 j$ & $3,255 \pm 30 \mathrm{e}$ \\
\hline \multicolumn{4}{|l|}{ Shampion (m) } \\
\hline \multicolumn{4}{|l|}{0} \\
\hline Harvest & $4,299 \pm 12 \mathrm{a}$ & $1,883 \pm 38 b$ & $3,388 \pm 29 \mathrm{e}$ \\
\hline \multicolumn{4}{|l|}{2} \\
\hline CONTROL & $3,719 \pm 13 b$ & $1,743 \pm 44 \mathrm{c}$ & $3,111 \pm 47 \mathrm{f}$ \\
\hline 1-MCP & $3,438 \pm 36 \mathrm{c}$ & $1,588 \pm 22 \mathrm{~d}$ & $3,002 \pm 31 \mathrm{~g}$ \\
\hline \multicolumn{4}{|l|}{4} \\
\hline CONTROL & $3,338 \pm 34 d$ & $1,490 \pm 19 \mathrm{e}$ & $2,933 \pm 46 \mathrm{~h}$ \\
\hline 1-MCP & $2,566 \pm 22 \mathrm{i}$ & $1,213 \pm 30 \mathrm{~g}$ & $2,896 \pm 32 \mathrm{i}$ \\
\hline \multicolumn{4}{|l|}{6} \\
\hline CONTROL & $3,247 \pm 27 \mathrm{e}$ & $1,383 \pm 36 \mathrm{f}$ & $2,970 \pm 28 \mathrm{~h}$ \\
\hline 1-MCP & $1,827 \pm 16 \mathrm{k}$ & $1,033 \pm 24 \mathrm{i}$ & $2,886 \pm 20 \mathrm{i}$ \\
\hline
\end{tabular}

Values are mean \pm standard deviation, $n=3$; in columns, mean values with different letters $(\mathrm{a}, \mathrm{b}, \mathrm{c} \ldots)$ are significantly different at $P<0.05$

$m$ month
[43]. Fruit with 1-MCP treatment was associated with lower lipoxygenase (LOX) and PPO activities, reduced $\mathrm{O}^{\circ}{ }^{-}$accumulation and maintenance of cell membrane integrity, decreased oxidation of polyphenols and thus retarded enzyme reactions involved in browning [44].

Effect of 1-MCP on fruit firmness and sensory attributes

Fruit firmness is one of the most important quality attribute for stored apple fruits [45]; therefore, all postharvest treatments that can control firmness are of great interest of fruit producers and researchers. 1-MCP due to specific ethylene action [9] can help to maintain fruit firmness but not in all cases. Generally, the firmness of apples declines when ethylene production or internal ethylene concentration increased. Apples treated at harvest with 1-MCP softened slower [10, 26, 46]. Presented results shows that in the case of 'Idared' cv. fruits with known good storability and with high initial firmness $(8.5 \mathrm{~kg})$, one can observe the decrease in stored fruits but no significant effect of neither storage nor 1-MCP treatment (Fig. 1). In the case of 'Shampion' cv. with $6.6 \mathrm{~kg}$ initial firmness on harvest time, fruits treated with 1-MCP significantly better retained firmness as compared with fruits stored without the treatment. It shows high usefulness of 1-MCP in 'Shampion' cv. storage.

The sensory characteristic of investigated fruits is given in Table 5. Comparing quality of fruit just after harvest, it was found that cultivar affects most of the investigated sensory attributes with the exception of ripe apple smell, crispness, crunchiness and the overall texture score. In general, 'Shampion' cv. got higher ranks for sweetness, taste and the overall quality, whereas 'Idared' cv. was perceived as
Fig. 1 Fruit firmness $(\mathrm{kg})$ in relation to cultivar storage and 1-MCP treatment

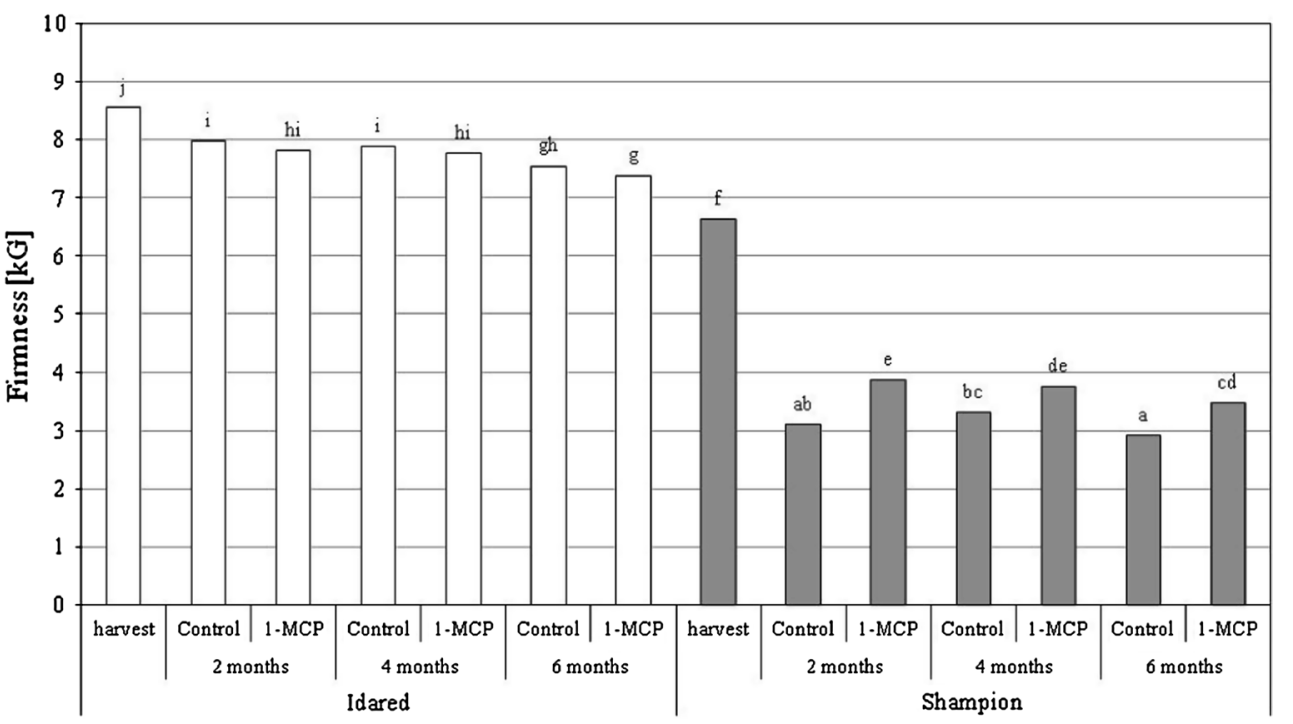


sourer, which is in arrangement with instrumental measurements (Fig. 1).

As concerns quality of stored apple, sweetness scores were stable during apple storage for both cultivars, whereas sourness scores only for 'Idared' cv.; in 'Shampion' cv., the decrease was found; however, no significant effect of 1-MCP was observed.

The hardness evaluated by expert panel was much higher for 'Idared' cv. as it was for fruit firmness measured mechanically (Fig. 1); this difference between cultivars may originate from structural differences in cell walls [47].

During storage in normal atmosphere, no effect of 1-MCP treatment or storage time was found for ripe apple smell, crispness, crunchiness and sweetness score.

For hardness, in case of 'Idared' cv., no effect of 1-MCP treatment was found, whereas for 'Shampion' cv., retarding effect of 1-MCP was observed (Table 5). These observations were in close arrangement with firmness measurements; moreover, it was found the high correlation between sensory and instrumental $\left(R^{2}=0.963\right)$. Fruit of 'Idared' cv. kept their juiciness and overall texture quality for 6-month storage but 'Shampion' cv. lost juiciness just after 2-month storage. It may be the indication of retarded harvest time for this cultivar as it may affect the storability [48]. However, 1-MCP significantly increased juiciness scores for fruits stored for 6 months, which probably influenced overall quality of fruits.

Overall texture for 'Shampion' cv. was lowest in all stored fruits without 1-MCP, while after 6-month storage, fruits with 1-MCP treatment got significantly better rank that all control samples.

Fruit flavor and the overall quality scores of 'Idared' cv. showed no effect of 1-MCP; this may be the effect of good storability of this cultivar. In the case of 'Shampion' cv., 1-MCP-treated fruit had better flavor and quality but the differences were not statistically significant.

\section{Conclusion}

The results of presented study demonstrate that treatment by 1-MCP is promising for the production of fruits rich in natural bioactive compounds. Apple storage after treatment by 1-MCP had positive effect on the quality of fruits by improving polyphenolic contents and antioxidant capacity.

The results of presented study demonstrate that apple after storage, especially 'Idared' cv., can be a valuable sensory attributes for food product. This study indicates that the use 1-MCP during long-term storage of apples is promising for the fruits designed for the direct consumption and also for the production of juices, rich in natural bioactive compounds.

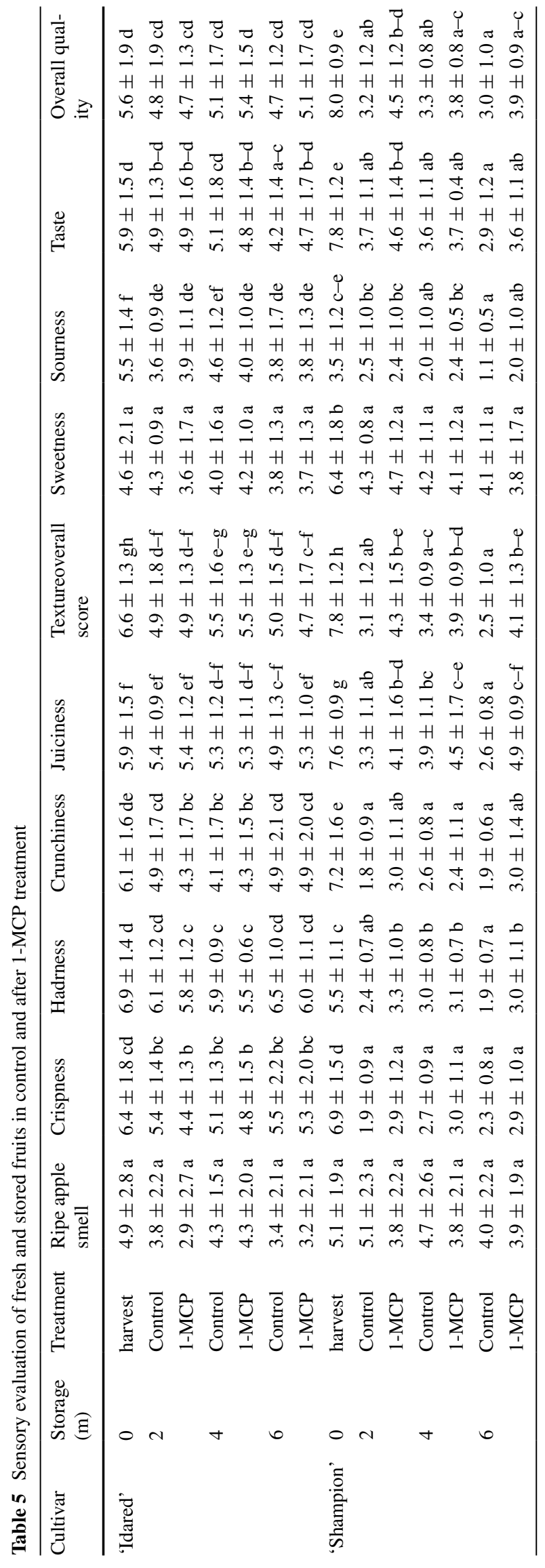


Acknowledgments This work was supported by the Ministry of Science and Higher Education of Poland (MNiSzW) under Grant MNiSzW NN312 199835.

\section{Conflict of interest None.}

Compliance with Ethics Requirements This article does not contain any studies with human or animal subjects.

Open Access This article is distributed under the terms of the Creative Commons Attribution License which permits any use, distribution, and reproduction in any medium, provided the original author(s) and the source are credited.

\section{References}

1. Le Marchand L, Murphy SP, Hankin JH, Wilkens LR, Kolonel LN (2000) J Natl Cancer Inst 92:154-160

2. Biedrzycka E, Amarowicz R (2008) Diet and health: apple polyphenols as 526 antioxidants. Taylor \& Francis 24:235-251

3. Kelloff GJ, Corwell JA, Steele VE, Lubet RA, Malone WA, Boone CW, Kopelovich L, Hawk ET, Lieberman R, Lawrence JA, Ali I, Sigman CC (2000) J Nutr 130:467-471

4. MacLean DD, Murr DP, Deell JR, Horvath CR (2006) J Agric Food Chem 54:870-878

5. Shoji T, Mutsuga M, Nakamura T, Kanda T, Akiyama H, Goda Y (2003) J Agric Food Chem 51:3806-3813

6. Kirca A, Arslan E (2008) Int J Food Sci Technol 43:2038-2046

7. Tomás-Barberán F, Espín JC (2001) J Sci Food Agric 81:853-876

8. Harker FR, Maindonald J, Murray SH, Gunson FA, Hallett IC, Walker SB (2002) Postharvest Biol Technol 24:225-239

9. Sisler EC, Serek M (1997) Plant Physiol 100:577-582

10. Blankenship SM, Dole JM (2003) Postharvest Biol Technol 28:1-25

11. Stafford HA (1990) Flavonoid metabolism. CRC Press, Boca Raton

12. Barz W, Köster J (1981) Turnover and degradation of secondary products. Biochem Plants Second Plant Prod 7:35-84

13. Hoang NTT, Golding JB, Wilkes MA (2011) Food Chem 127:1249-1256

14. Kolniak-Ostek J, Oszmiański J, Wojdyło A (2013) Ind Crops Prod 44:413-420

15. Wojdyło A, Oszmiański J, Laskowski P (2008) J Agric Food Chem 56:6520-6530

16. Benzie IFF, Strain JJ (1996) Anal Biochem 239:70-76

17. Yen GC, Chen HY (1995) J Agric Food Chem 43:27-32

18. Re R, Pellegrini N, Proteggente A, Pannala A, Yang M, RiceEvans C (1999) Free Radic Biol Med 26(9/10):1231-1237

19. PN-90/A-75101/03 Fruit and vegetable products. Preparation of samples for physico-chemical studies. Determination of dry matter content by gravimetric method

20. PN-90/A-75101/04 Fruit and vegetable products. Preparation of samples and test methods. Determination of total acidity
21. ISO 8589: 1998: Sensory analysis-general guidance for the design of test rooms (PN-ISO 8589: 1998: Analiza sensoryczna Ogólne wytyczne dotyczące projektowania pracowni analizy sensorycznej)

22. Siksnianas T, Stanys V, Sasnauskas A, Viskelis P, Rubinskiene M (2006) J Fruit Ornam Plant Res 14(2):265-271

23. Payasi A, Sanwal GG (2010) J Food Biochem 34(4):679-710

24. Lapsley KG, Escher FE, Hoehn E (1992) Food Struct 11:339-349

25. De Smedt V, Pauwels E, De Baerdemaeker J, Nicolai B (1998) Post Biol Technol 14:151-158

26. Johnston JW, Hewett EW, Hertog MLATM (2002) N Z J Crop Hortic Sci 30:145-160

27. Yiwei M, Deqiang G, Guobin L, Ruihong H, Jianghui X, Weicai L (2008) J Sci Food Agric 88:2693-2699

28. Mullen W, Marks SC, Crozier A (2007) J Agric Food Chem 55(8):3148-3157

29. Tsao R, Yang R, Young JC, Zhu H (2003) J Agric Food Chem 51:6347-6353

30. Oszmiański J, Wojdyło A, Kolniak J (2009) J Agric Food Chem 57(15):7078-7085

31. Napolitano A, Cascone A, Graziani G, Ferracane R, Scalfi L, Di Vaio C, Ritieni A, Fogliano V (2004) J Agric Food Chem 52:6526-6531

32. Hoang NTT, Golding JB, Wilkes MA (2011) Food Chem 127(3):1249-1256

33. Eberhardt MV, Lee CY, Liu RH (2000) Nature 405:903-904

34. Thielen C, Will F, Zacharias J, Dietrich H, Jacob H (2004) Dtsch Lebensm-Rundsch 100:389-398

35. Watzl B, Leitzmann C (1999) Bioaktive Substanzen in Lebensmitteln, 2nd edn. Hippokrates, Stuttgart [Conn, E., E., Editor; Academic Press: New York]

36. Wojdyło A, Oszmiański J, Bober I (2008) Eur Food Res Technol 227:1043-1051

37. Wojdyło A, Figiel A, Lech K, Nowicka P, Oszmiański J (2014) Food Bioprocess Technol 7:829-841

38. Hwang JH, Myoung-Won K, Young-Hee K (1994) J Plant Biol $37: 263-269$

39. Ritenour MA, Ahrens MJ, Saltveit ME (1995) J Am Soc Hortic Sci 120:84-87

40. Salah N, Miller NJ, Paganga G, Tijburg L, Bolwell GP, RiceEvans C (1995) Arch Biochem Biophys 322:339-346

41. Rice-Evans CA, Miller NJ, Paganga G (1997) Trends Plant Sci 2:152-159

42. Horubała A (1999) Ind Ferment Fruit Veg 3:30-32 (in polish)

43. Grajek W (2003) Food Learn Technol Qual 4(37):26-35

44. Cai C, Chen KS, Xu WP, Zhang WS, Li X, Ferguson I (2006) Postharvest Biol Technol 40:155-162

45. DeEll JR, Khanizadeh S, Saad F, Ferree DC (2001) Rev J Am Pomol Soc 55(1):8-27

46. Watkins CB (2006) Biotechnol Adv 24:389-409

47. Nara K, Kato Y, Motomura Y (2001) Post Biol Technol 22:141-150

48. Kviklienè N, Valiuškaitè A (2009) Scientific works of the lit. Inst Hortic Lith Univ Agric 28(3):117-123 